\title{
HIV/AIDS knowledge, sexual behaviour and condom use among commercial motorcyclists in Lagos State, Nigeria
}

\author{
Winifred Aitalegbe OJIEABU* and Uchenna Ifeyinwa Helen EZE \\ Department of Clinical Pharmacy and Biopharmacy, Faculty of Pharmacy, Sagamu, Olabisi Onabanjo \\ University, Ago Iwoye, Ogun State, Nigeria. \\ Corresponding author, E-mail: natbelpharmacy@yahoo.com; Tel: 08037126245.
}

\begin{abstract}
The incidence of HIV/AIDS infection within our society has gotten to an alarming proportion especially as it affects our youths, the group to which majority of our commercial motorcyclists belong. This prompted the need to assess the level of awareness, knowledge and preventive measures by these stakeholders towards HIV/AIDS in the face of cultural beliefs, habits and ignorance. A total number of 345 questionnaires containing well-structured questions relating to the subject matter were administered to commercial motorcyclists selected through purposive sampling technique at different locations in Lagos State. Majority (72.7\%) of the respondents were of the age range 20-39 years, of polygamous families (74.5\%), Moslems $(65.5 \%)$, with secondary education $(58.3 \%)$. All the respondents were aware of HIV/AIDS. Respondents identified virus $(84.3 \%)$, bacteria $(3.5 \%)$ and excessive drinking of alcohol $(8.7 \%)$ as some of the causes of HIV/AIDS. Some ways of contacting it included penetrative sex (96.2\%), sharing shaver blade (57.1\%) and maternal transmission (48.7\%). Cases of misconception abound. Respondents who indicated they sometimes use condom were $64.6 \%$. Those who had no sexual partners apart from their wives were $70.7 \%$. The men in this study only had high HIV/AIDS awareness and adequate knowledge in some areas, but lack such in other key areas and therefore do not possess sufficient knowledge to curtail the spread of this killer disease. Education and condom promotion should be part of every national AIDS control program.
\end{abstract}

(C) 2011 International Formulae Group. All rights reserved.

Keywords: HIV/AIDS knowledge, Sexual behaviour, Okada riders, Condom use.

\section{INTRODUCTION}

Human immunodeficiency virus and Acquired immune deficiency syndrome (HIV/AIDS) has remained a great challenge to human life with the ability to erode social and economic development. The region of the world mostly affected being Sub- Saharan Africa (UNAIDS, 2003). The prevalence is highest among productive young people between the ages of 20-29 years, with $60 \%$ of new cases occurring in the 15-25year- old age group (FMH, 2006; USAIDS, 2003). Joint
United Nations Program on HIV/AIDS (UNAIDS) estimated 33.4 million people living with HIV globally in 2008 (UNAIDS, 2009) and about 3.11 million people are estimated to be living with HIV in Nigeria by the end of 2010 , thereby making about $9 \%$ of the global HIV burden (FMH, 2010). Heterosexual transmission accounts for $80 \%$ of all HIV infections in Nigeria (USAIDS, 2003). The HIV epidemic in Nigeria is characterized by one of the most rapidly increasing rates of new HIV/AIDS cases in 
West Africa (HIV/AIDS). This infection rate, although lower than that of neighbouring African countries, should be considered in the context of Nigeria's relatively large population. In 2007 alone, approximately 170,000 people died from AIDS (UNAIDS, 2008). With AIDS contributing to loss of so many lives, Nigeria's life expectancy has declined from the average life expectancy of 53.8 years for women and 52.6 years for men in 1991 to 46 for women and 47 for men in 2007 (WHO, 2008).

Some sub-groups of the population, such as female sex workers and long distance drivers, have been shown to be particularly at increased risk of exposure to HIV (Hope, 2001).

HIV/AIDS Integrated Biological and Behavioural Surveillance Survey (IBBSS) was conducted in 2007 among subpopulations whose behaviours or occupations expose them to higher risk of acquiring or contracting sexually transmitted infections (STI). These sub-groups included men who have sex with men (MSM), female sex workers (FSW), intravenous drug users (IDU), transport workers (TW) and uniformed service personnel. The survey was conducted across five states namely: Anambra, Cross River, Edo, Kano, Lagos and the Federal Capital Territory (FCT) with the objectives of obtaining baseline data on risk behaviour; determining the prevalence of HIV infection and syphilis; and assessing their knowledge and beliefs about STI (FMH, 2007). HIV prevalence was highest among female brothelbased sex workers (37.4\%); followed by nonbrothel-based sex workers (30.2\%); MSM $(13.5 \%)$; IDU (5.6\%); transport workers (3.7\%); police $(3.5 \%)$ and armed forces (3.1\%).

These sub-populations engaged in multiple partnerships in the past 12 months of the survey with armed forces, police and transport workers having $37.3 \%, 29.4 \%$ and $37.9 \%$ respectively (Rhodes and Simic, 2005; Beyrer, 2007).

A study in which the knowledge and attitudes of long distance truck drivers concerning sexually transmitted diseases (STD) and sexual behaviour were surveyed revealed that 317 (99\%) of the subjects had heard of AIDS and were aware of the correct risk-reducing behaviour. Though they knew the use of condoms can prevent the transmission/acquisition of sexually transmitted diseases (STDs), only 32\% had ever used condoms despite the fact that $61 \%$ admitted to visiting prostitutes. (Bwayo et al., 1991). Surveys in Republic of Benin have recorded figures of condom use with a recent non- regular partner as low as $20 \%$ amongst men with no formal education, $18-19 \%$ in those with primary education and 39\% in those with secondary education and above ( UNICEF, 2000). United Nations against AIDS (UNAIDS, 2008) estimated that only 18 percent of women and 21 percent of men between the ages of 15 and 24 correctly identify ways to prevent HIV. Lack of accurate information about sexual health has meant there are many myths and misconceptions about sex and HIV, contributing to increasing transmission rates as well as stigma and discrimination towards people living with HIV/AIDS.

Literature about the motorcycle, as a commercial means of transportation is relatively scarce because it is a new venture in Nigeria. Although many programs for the prevention of HIV/AIDS and other sexually transmitted diseases are being carried out in Nigeria, the commercial motorcyclists, a group similar to long distance drivers, have been virtually overlooked in the dynamics of urban HIV and their role as potential carriers of HIV/STDs. The commercial motorcyclists are exposed daily to very close interaction with different segments of the population with their divergent views about the infection. It is suspected that this interaction may be one of many ways that expose them to multiplicity of sexual partners hence this study which aimed at assessing HIV-related knowledge and sexual behaviour, particularly condom use, among commercial motorcyclists (otherwise known as okada riders) in Lagos State, Southwestern Nigeria with a view of finding 
an effective way to curb this rapid spreading menace from our society.

\section{MATERIALS AND METHODS \\ Study population}

The population of this study comprised of consecutively selected commercial male motorcyclists in some locations in Lagos which was done using purposive sampling technique. Three hundred and fifty five (355) questionnaires were administered but only 345 were properly filled and used for this study. There was no strict parameter on the choice of the people given the questionnaire apart from the facts that they were not administered to non-commercial motorcyclists but to men actively engaged in this type of occupation irrespective of tribe.

\section{Study design}

This was a cross sectional descriptive carried out among commercial motorcyclists in Lagos.

\section{Research instrument}

The primary instrument for this research was the questionnaire which was sub-divided into three sections, namely:

-Socio-demographic characteristics of the respondents

-Knowledge about HIV/AIDS

-Sexual behaviour and condom use.

\section{Data presentation and analysis}

The information obtained from the questionnaire administration was collated, coded and presented in tabular form which was analyzed using simple arithmetic percentages.

\section{Ethical issues}

Consent was sought from the respondents and the purpose of this research was carefully explained to them before filling the questionnaires.

\section{RESULTS}

\section{Socio-demographic characteristics of respondents}

Majority (44.3\%) of the respondents were of the age range 30-39 years, mostly of polygamous families $(74.5 \%)$ and $65.5 \%$
Moslems. Many of them had tertiary $(33.9 \%)$ and secondary school (58.3\%) education with majority of those in this business being students $(31 \%)$. The unemployed was $31 \%$ while majority (45\%) were married and living with their spouses (Table 1).

\section{Respondents' knowledge of HIV/AIDS}

All the respondents $(100 \%)$ were aware of HIV/AIDS as they had all heard about it. Their most viable source of information was the radio $(62.3 \%)$ while other sources included the television $(26.4 \%)$ and billboard adverts $(24.9 \%)$. Majority of the respondents $(84.3 \%)$ identified virus as the cause of HIV/AIDS while few identified bacteria $(3.5 \%)$, evil spirit/witchcraft $(1.2 \%)$, fungi $(2.3 \%)$ and excessive drinking of alcohol $(8.7 \%)$.

Sources of contacting HIV/AIDS identified mostly by the respondents included the following : "penetrative sex (96.2\%)", "Sharing injection needles (73.4\%)", "penetrative anal sex (61.2\%)", "blood transfusion $(60.3 \%)$ ", "sharing shaver blade $(57.1 \%)$ " and "maternal transmission $(48.7 \%)$ respectively". "Avoid sex with prostitutes $(96.8 \%)$ )", with infected persons (95.1\%)", avoid transfusion of unscreened blood $(88.1 \%)$ ", "not sharing injection needles $(83.8 \%)$ ", "use of condom (58.3\%)" ,"being faithful to one partner $(57.7 \%)$ " and "avoid casual sex (54.2\%)" were some ways of preventing HIV/AIDS identified by respondents. Respondents believed that HIV/AIDS persons can live good life if well managed $(83.5 \%)$, a healthy looking person can have HIV/AIDS (85.2\%) while $81.4 \%$ believed that a healthy looking person can infect others with the AIDS virus. Cases of misconception abound as minor percentage of respondents identified mosquito bites, living in the same house, sharing the same bed, sharing food, public toilets, kissing and hugging, through sneezing, coughing and shaking hands with HIV persons as additional ways of contacting HIV/AIDS. Respondents believing that an HIV positive person can never survive $(15.1 \%)$ or can be fully cured 
$(1.4 \%)$ are other forms of misconception about this pandemic (Table 2).

\section{Sexual behaviour of respondents}

Respondents who indicated they sometimes used condom were $64.6 \%$, always used condom $(28.7 \%)$ and never used it $(6.7 \%)$. Those who had no sexual partners apart from their wives $(70.7 \%)$ were in the majority as compared to those who had multiple sexual partners including their wives $(29.3 \%)$. As at the time the respondents started using condom for sex, the following were cited; since I got married (22.6\%), before I got married (32.2\%), when my wife got pregnant (16.5\%) (Table 3 ).

Table1: Socio-demographic characteristics of respondents.

\begin{tabular}{|c|c|c|}
\hline Age (Years) & Frequency & Percentage \\
\hline $20-29$ & 98 & 28.4 \\
\hline $30-39$ & 153 & 44.3 \\
\hline $40-49$ & 62 & 18.0 \\
\hline $50-59$ & 32 & 9.3 \\
\hline Total & 345 & 100 \\
\hline \multicolumn{3}{|l|}{ Family: } \\
\hline Monogamous & 88 & 25.5 \\
\hline Polygamous & 257 & 74.5 \\
\hline Total & 345 & 100 \\
\hline \multicolumn{3}{|l|}{ Religion: } \\
\hline Christianity & 102 & 29.6 \\
\hline Moslem & 226 & 65.5 \\
\hline Tradition & 17 & 4.9 \\
\hline No religion & 0.0 & 0.0 \\
\hline Total & 345 & 100 \\
\hline \multicolumn{3}{|l|}{ Education: } \\
\hline No formal Education & 5 & 1.4 \\
\hline Primary school & 22 & 6.4 \\
\hline Secondary & 201 & 58.3 \\
\hline Tertiary Education & 117 & 33.9 \\
\hline Total & 345 & 100 \\
\hline \multicolumn{3}{|l|}{ Occupation: } \\
\hline Civil servants & 26 & 7.5 \\
\hline Health Professional & 17 & 4.9 \\
\hline Business Professional & 86 & 24.9 \\
\hline Students & 109 & 31.6 \\
\hline Unemployed & 107 & 31.0 \\
\hline Total & 345 & 100 \\
\hline \multicolumn{3}{|l|}{ Marital: } \\
\hline Live together & 157 & 45.5 \\
\hline Separated & 118 & 34.2 \\
\hline Single & 70 & 20.3 \\
\hline Total & 345 & 100 \\
\hline
\end{tabular}


Table 2: Respondents' knowledge of HIV/AIDS.

\begin{tabular}{|c|c|c|}
\hline Sources of information & Frequency & Percentage \\
\hline Television & 91 & 26.4 \\
\hline Radio & 215 & 62.3 \\
\hline Education program & 17 & 4.9 \\
\hline Medical sources & 1 & 0.3 \\
\hline Internet & 2 & 0.6 \\
\hline Public lectures & 47 & 13.6 \\
\hline National Newspaper & 29 & 8.4 \\
\hline Bill boards advert & 86 & 24.9 \\
\hline \multicolumn{3}{|l|}{ Cause of HIV/AIDS } \\
\hline Bacteria & 12 & 3.5 \\
\hline Evil spirit/witchcraft & 4 & 1.2 \\
\hline Virus & 291 & 84.3 \\
\hline Fungi & 8 & 2.3 \\
\hline Excessive drinking of Alcohol & 30 & 8.7 \\
\hline Total & 345 & 100 \\
\hline \multicolumn{3}{|l|}{ Ways of contact } \\
\hline Mosquitoes bites & 18 & 5.2 \\
\hline Penetrative sex & 332 & 96.2 \\
\hline Penetrative anal sex & 211 & 61.2 \\
\hline Contact with blood of HIV person & 107 & 31.0 \\
\hline Living in the same house & 3 & 0.9 \\
\hline Sharing the same bed & 22 & 6.4 \\
\hline Sharing injection needles & 252 & 73.4 \\
\hline Sharing foods & 9 & 2.6 \\
\hline Public toilets & 37 & 10.7 \\
\hline Sharing shaver blade & 197 & 57.1 \\
\hline Blood transfusion & 208 & 60.3 \\
\hline Kissing and Hugging & 2 & 0.6 \\
\hline Maternal transmission & 168 & 48.7 \\
\hline Through sneezing \% coughing & 9 & 2.6 \\
\hline Shaking hands with HIV persons & 4 & 1.2 \\
\hline \multicolumn{3}{|l|}{ Ways of protecting } \\
\hline Avoid casual sex & 187 & 54.2 \\
\hline Use of condom & 201 & 58.3 \\
\hline Avoid sex with infected persons & 328 & 95.1 \\
\hline Avoid sex with prostitute & 334 & 96.8 \\
\hline Not sharing injection needle & 289 & 83.8 \\
\hline Avoidance of infected person & 177 & 51.3 \\
\hline Be faithful to one partners & 199 & 57.7 \\
\hline Avoid anal sex & 168 & 48.7 \\
\hline Avoid sex before marriage & 79 & 22.9 \\
\hline Avoidance of transfusion of Unscreened blood & 304 & 88.1 \\
\hline Abstain from penetrative sex & 162 & 47.0 \\
\hline \multicolumn{3}{|l|}{ Fate of the HIV/AIDS infected person } \\
\hline Can be cured fully & 5 & 1.4 \\
\hline
\end{tabular}




\begin{tabular}{lcc}
\hline Can live good life if managed & 288 & 83.5 \\
Can never survive & 52 & 15.1 \\
Total & 345 & 100 \\
Healthy person can live with HIV/AIDS & 285 & 85.2 \\
Yes & 51 & 14.8 \\
No & 345 & 100 \\
Total & & \\
Healthy looking person can infect others with AIDS Virus & 281 & 81.4 \\
Yes & 64 & 18.6 \\
No & 345 & 100 \\
Total & & \\
\hline
\end{tabular}

Table 3: Sexual behaviour of the respondents.

\begin{tabular}{lcc}
\hline Condom use & Frequency & Percentage \\
\hline Always & 99 & 28.7 \\
Sometimes & 223 & 64.6 \\
Never & 23 & 6.7 \\
Total & 345 & 100 \\
Having sexual partner apart from ones wife: & & \\
Yes & 101 & 29.3 \\
No & 244 & 70.7 \\
Total & 345 & 100 \\
Time the respondents started using condom: & & \\
Since i got married & 78 & 22.6 \\
Before I got married & 111 & 32.2 \\
When my wife got pregnant & 57 & 16.5 \\
Never & 99 & 28.7 \\
Total & $\mathbf{3 4 5}$ & $\mathbf{1 0 0}$ \\
\hline
\end{tabular}

\section{DISCUSSION}

Respondents comprised mostly of youths within the ages of 20-39 years which is the most economically productive age group and also the group most likely to be involved in high risk sexual behaviour in our society. Studies have documented an increased exposure to risks of sexually transmitted infections amongst these young people (Ajuwon et al., 2001; Dare et al., 2001).

Their family type was mostly polygamous in nature which can invariably contribute to HIV spread as multiple sexual partners and unprotected sexual activities are forms of risky sexual behaviour (Onwuamanam, 1995).
All the respondents assessed have heard about HIV/AIDS which made their awareness level very satisfactory. This is similar to the reports about pregnant women in Enugu and Abakaliki (Obi et al., 2001; Ibekwe \& Ikeme, 2003) where over $80 \%$ of young adults knew about HIV/AIDS. In 2005, a campaign was launched in Nigeria in a bid to raise more public awareness of HIV/AIDS. This campaign took advantage of the recent increase in owners of mobile phones and sent text messages with information about HIV/AIDS to 9 million people (BBC News, 2005). Also a radio serial, "Future Dreams", broadcasted in 2001 in nine languages and aired on 42 radio channels was used in encouraging consistent condom use, 
increasing knowledge and increasing skills for condom negotiation in single men and women aged between 18 and 34 (Population, 2003 ). Exposure to HIV/AIDS information through mass media only lead to high levels of awareness without a corresponding increase in knowledge as demonstrated by these respondents since they could not adequately identify all the seven and ten routes by which HIV/AIDS can be contacted and prevented respectively as listed in this study. This study suggests a case of ever hearing and never doing. Podhisita et al. (1996) found a high percentage of truck drivers that had the knowledge of how to prevent HIV/AIDS transmission, but their attitude on their susceptibility reflected the practice of not using condoms. Another researcher ( Prohaska, 1990 ), found that neither increased exposure to the media, greater belief in the accuracy of the media as a source of information about AIDS nor knowledge of the facts about HIV/AIDS transmission affected people's perception of risk.

Although majority of the respondents could identify virus as the causative organism of HIV/AIDS and some of the ways by which HIV/AIDS can be contacted and prevented, there were however a lot of misconceptions recorded in this study. Such misconceptions included many of the respondents believing that bacteria, evil spirit/witchcraft, fungi and excessive drinking of alcohol can cause HIV/AIDS, mosquito bites; living in the same house, sharing the same bed or food, public toilets, kissing and hugging, sneezing and coughing, and shaking hands as ways of contacting the disease while avoidance of infected person was identified as a way of protection against HIV/AIDS. Other misconceptions recorded included: HIV/AIDS infected person can be fully cured, can never survive, healthy looking person can not have HIV/AIDS and cannot also infect others with the AIDS virus. Previous studies also recorded these misconceptions (Peltzer and Promtussananon, 2005; Unigbe and Ogbeide, 2005; Ojieabu et al., 2008). UNAIDS (2003) noted that general awareness of AIDS is no longer important in AIDS prevention but accurate knowledge of how HIV is transmitted. For example if people believe that mosquitoes transmit the HIV virus, they may see the use of condoms as unnecessary.

There was low condom use in this study despite the fact that a good percentage of the respondents claimed to be involved in extra-marital sexual affairs. Similar low rates of condom use have been reported in another study (Gorgen et al., 1998). Our study is also similar to that in which the knowledge and attitudes of long distance truck drivers concerning sexually transmitted diseases (STD) and sexual behaviour was surveyed. Though they knew the use of condoms can prevent the transmission/acquisition of STDs, only few ever used despite the fact that $61 \%$ admitted to visiting prostitutes (Bwayo et al., 1991). Few people use condoms in steady relationships. In Nigeria, for example, $2 \%$ of respondents report always using condoms with a spouse or "concubine," compared to $33 \%$ for boyfriends and girlfriends and 67\% for casual partners (Van Rossem et al., 2001). Earlier reports (Rakwar et al., 1999; Rao et al., 1999) have identified drivers, especially those covering inter-regional long distances, as clients of prostitutes at truck stops along their routes. Individual-level risks for HIV acquisition and transmission within subpopulations are critical in the diverse ongoing epidemics and are impacted by social, structural, and sub-population-level risks and protections (Rhodes and Simic, 2005; Beyrer, 2007). A sub-analysis by gender among the police force indicated a higher HIV prevalence among women especially in Federal Capital Territory, Abuja. It was suggested that consistent condom use among their male counterpart may be responsible for lower HIV prevalence. (FMH, 2007)

About 30 percent of the respondents in our study indicating having multiple sexual partners suggests that motorcyclists in Lagos may be at risk of sexually transmitted disease including HIV as multiplicity of sexual partners is the greatest risk factor implicated in the spread of the HIV/AIDS pandemic. 
Although, the practice of safer sex with the use of condom can prevent HIV transmission, the inability to negotiate for condom use is often reflected in the socioeconomic status of partnerships, which subjugates women to concede to unsafe sex (Munakata, 2003).

Studies that have evaluated condom effectiveness amongst heterosexual couples have also shown that consistent condom use is protective against HIV and rates of transmission of less than $1 \%$ per year have been reported amongst consistent condom users (Deschamps et al., 1996).

\section{Conclusion}

The men in this study only had high HIV/AIDS awareness level and adequate knowledge in some areas, but lack such in other key areas and therefore do not possess sufficient knowledge to curtail the spread of this killer disease and hence a high risk group for acquiring HIV infection. Their lack of sufficient HIV/AIDS related - knowledge in all key areas, refusal to use condom and undisciplined sexual behaviour with a variety of women within and outside their parks meant that they play a major role in transmitting HIV infection in urban communities in Nigeria. There is an urgent need for intervention programs such as education with a focus on motorcyclists and similar high risk groups which could be delivered to them on a regular basis through popular radio stations at their okada parks. In addition, condom promotion should be part of every national AIDS control program because every country includes people for whom condoms are the best option to reduce HIV/AIDS risk.

\section{REFERENCES}

Ajuwon AJ, Fawole F, Osungbade K. 2001. Knowledge of AIDS and sexual practices of young female hawkers in truck and bus stations in Ibadan, Nigeria. Int'l Quarterly of Community Health Education, 20(2): 131-141.

Beyrer C. 2007. HIV Epidemiology Update and Transmission Factors: Risks and Risk
Contexts-16 ${ }^{\text {th }}$ International AIDS Conference Epidemiology Plenary. Clinical Infectious Diseases., 44: 981-7.

British Broadcasting Corporation News. 2005. 'Texts used for Nigeria HIV drive'.

Bwayo JJ, Mutere AN, Omari MA, Kreiss JK, Jaoko W, Sekkade-Kigondu C, Plummer FA. 1991. Long distance truck drivers: knowledge of attitudes concerning sexually transmitted and sexual behaviour. E Afr Med J., 68(9): 174-179.

Dare OO, Oladepo O, Cleland JG, Badru OB. 2001. Reproductive health needs of young persons in markets and motor parks in South West Nigeria. Afr. J. Sci., 30: 199-205.

Deschamps MM, Pape JV, Hafner A, Johnson WD Jr. 1996. Heterosexual transmission of HIV in Haiti. Annals of Internal Med., 125(4): 324-330.

Federal Ministry of Health of Nigeria. 2006. (FMOH)/National HIV/AIDS and STI Control Programme (HAST). The 2005 National HIV Seroprevalence Sentinel Survey. Abuja: FHOMH/HAST.

Federal Ministry of Health. 2007. Integrated Bio-Behavioural Surveillance Survey Among Most at Risk Populations in Nigeria. Abuja: National AIDS/STIs Control Programme (NASCP), Nigeria (IBBSS).

Federal Ministry of Health. 2010. Technical Report on the 2008 National HIV/Syphilis Seroprevalence Sentinel Survey Among Pregnant Women Attending Antenatal Clinics in Nigeria. Department of Public Health National AIDS/STI Control Programme. Abuja: Nigeria.

Gorgen R, Yansane ML, Marx M, Millimounou D. 1998. Sexual behaviour and attitudes among unmarried urban youths in Guinea. Inter Fam Plann Persp., 24: 65-71.

HIV/AIDS in Nigeria. A USAID Brief http://pdf.usaid.gov/pdf_docs/Pnacq945.p df (Accessed January 30, 2010).

Hope KR. 2001. Population mobility and multi-partner sex in Botswana: 
Implications for the spread of HIV/AIDS. Afr. J. Reprod. Health, 5: 74-83.

Ibekwe PC, Ikeme ACC. 2003. The knowledge and attitude of pregnant women toward HIV infection. Ebonyi. Med. Jour., 2(2): 13-17.

Joint United Nations Programme on HIV/AIDS (UNAIDS). 2003. New York. "AIDS epidemic update"

Joint United Nations Programme on HIV/AIDS (UNAIDS). 2008. AIDS epidemic update: Global summary of the AIDS epidemic.

Joint United Nations Programme on HIV/AIDS (UNAIDS). 2009.

AIDS epidemic update: Global summary of the AIDS epidemic.

Munakata T. 2003. Are females sexually unassertive? - A study of Nigeria, Thailand, China and Japan young adults. Journalist against AIDS (JAAIDS) in Nigeria. Www.jaaids.org Accessed 10/6/10.

Obi SN, Ezeonu P, Ezegwui HC. 2001. Level of HIV/AIDS awareness and the acceptability of HIV screening among pregnant women in Abakaliki Nigeria. Trop. J. Obstet Gynae., 18(1): 13.

Ojieabu WA, Erah PO, Okafor NA. 2008. HIV/AIDS- Related knowledge and sexual behaviour among secondary school students in Benin City. International Journal of Health Research., 1(1): 27-37.

Onwuamanam DO. 1995. Sexual networking among youth in Southwestern Nigeria. Health Transition Review Supplement., 5: 57-66.

Peltzer K, Promtussananon S. 2005. HIV/AIDS knowledge and sexual behaviour among junior secondary students in South Africa. J. Soc. Sci., 1(1): 1-8.

Podhisita C, Wawer MJ, Pramualratana A. 1996. Multiple sexual partners and condom use among long- distance truck drivers in Thailand. AIDS Educ Prevn., 8: $490-8$.
Population Services International. 2003. Nigerian radio campaign generates safer behaviour .

Prohaska TR, Albrecht G, Levy JA, Sugrue N, Kim J. 1990. Determinants of selfperceived risk for AIDS. J. Hlth. Social Behav., 31: 384-394.

Rakwar J, Lavreys L, Thompson ML, Jackson D, Bwayo J, Hassanali S, Mandaliya K, Ndinya- Achola J, Kreiss J. 1999. Cofactors for the acquisition of HIV-1 among heterosexual men: prospective cohort study of trucking company workers in Kenya. AIDS., 13(5): 607-614.

Rao KS, Pilli RD, Rao AS, Chalam PS. 1999. Sexual life of long distance lorry drivers in India: questionnaire survey. $\mathrm{Br}$. Med. J., 318: 162-163.

Rhodes T, Simic M. 2005. Transition and the HIV risk environment. BMJ., 331: 220223.

UNICEF. 2000. Macro International Demographic and Health Survey (Benin) 1995 - 2000

Unigbe IE, Ogbeide 2005. Sexual behaviours and perception of AIDS among adolescent girls in Benin-City, Nigeria. Afr. J. Reprod Health, 3(1): 39-44.

United States Aids for International Development (USAIDS). 2003. Nigeria Country Profile (HIV/AIDS), www.usids.gov/location/sub-Saharanafrica/ countries/Nigeria. Accessed on 06/07/ 2010.

Van Rossem R, Meekers D, Akinyemi Z. 2001. Consistent condom use with different types of partners: evidence from two Nigerian surveys. AIDS Educ Prev., 13(3): 252-267.

World Health Organization. 2008. 'WHO African Region: Nigeria. 